\section{India approves use of genetically modified crops, despite critics}

[NEW DELHI] Undeterred by criticism from environmental groups, the Indian government announced last week that it will encourage the use of genetically modified seeds in agriculture, and give high priority to transgenic crop research.

It says high priority is necessary because of the "urgency to enhance food production and develop crops with desired traits". But government officials assured critics that the 1998 revised recombinant DNA safety guidelines and biosafety protocols would be fully observed during research and field trials and before modified seeds were marketed.

The announcement came in a statement from heads of agricultural research, the Department of Biotechnology (DBT) and regulatory committees, who held a press conference in New Delhi in the wake of mounting protests against the controversial trials of $B t$ cotton by Monsanto in nine Indian states.

Angry farmers in Karnataka state recently burned experimental fields there (see Nature 396, 397; 1998), and the government of Andhra Pradesh stopped the trials. Earlier this month, the Research Foundation for Science, Technology and Ecology (RFSTE), a non-governmental organization in Delhi, issued a lawsuit against DBT in the Delhi high court for authorizing the trial and bypassing the ministry of the environment.

At the press conference, however, the officials claimed the Monsanto trials could lead to an annual saving in the use of pesticides of $\$ 375$ million, and accused critics of misleading the environmental groups.

"With 60 million acres of transgenic plants under cultivation worldwide, India cannot lag behind others in this technology," said Manju Sharma, secretary of DBT. She said that DBT is funding transgenic research in tobacco, rice, wheat and potato and has given permission to three other private companies for field trials of mustard, tomato and cauliflower. The $\$ 100$ million given by the World Bank to the national agricultural technology project would be used for major research in transgenic crops, say the officials.

According to Asis Datta, chairman of the DBT committee that approved the Monsanto trials, $B t$ cotton was grown in a plot of 25 square metres and then in five plots, each of 200 square metres, before being approved for one-acre fields in $\mathbf{4 0}$ locations nationwide.

Vandana Shiva, president of RFSTE, says the trials are illegal because planting started in June last year, before official permission was given in July, and they were not cleared by the Genetic Engineering Approval Committee of the Ministry of the Environment, which has the final say.

K.S. Jayaraman

\title{
Physicist's dual role could help with Japanese merger
}

[TOKYo] Physicist Akito Arima, former president of Tokyo University and currently Japan's education minister, is to take up an additional post as director-general of the Science and Technology Agency (STA).

The appointment of Arima, an outspoken supporter of reforms in the organization of Japanese science, is seen by many as likely to increase the success of the merger of STA and the Ministry of Education, Science, Sports and Culture (Monbusho) in two years' time (see Nature 390,327; 1997).

It follows the departure last week of three cabinet ministers, including Yutaka Takeyama, the current director-general of STA, as part of a cabinet reshuffle at the launch of a coalition between the ruling Liberal Democratic Party (LDP) and the Liberal Party.

The leaders of both parties reached an agreement on 13 January, ending a series of talks aimed at ironing out policy differences, especially on security issues. The coalition government was launched on 14 January in time for the start of the ordinary session of the Diet, Japan's parliament, on Tuesday (19 January).

Keizo Obuchi, Japan's prime minister and the LDP's leader, reduced the number of ministers from 20 to 18 by merging several ministerial posts, including those for STA and Monbusho, as well as those for the Ministry of Construction and the Land Development Agency.

Despite speculation that Arima, who is relatively inexperienced in politics, would be the first to leave the cabinet, Obuchi instead asked for voluntary resignations from ministers of his own political faction.

After resigning as director of STA's Institute of Physical and Chemical Research (RIKEN) last year, Arima was elected to the upper house of the Diet on LDP's proportional representation list (see Nature 394, 512; 1998) and, just two weeks later, was appointed education minister in Obuchi's new cabinet.

He introduced the first external review system to a Japanese university and helped draft the 1996 Basic Law for Science and Technology, designed to increase Japan's spending on science by 50 per cent by 2001 .

Japanese scientists have shown strong support for Arima's appointment as the head of STA, especially as many were concerned about its incompatibility with Monbusho, which has an education-orientated, 'bottom-up' approach to research, as opposed to STA's 'top-down' approach. They hope that Arima's experience of both worlds will enable him to help resolve conflicts between the cultures of the two agencies.

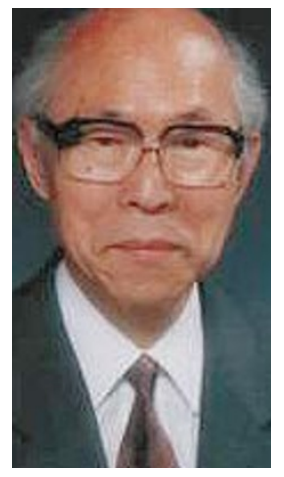

Arima: 'at home with STA and Monbusho'.

cou could fulfil the role as busho" says Minoru Oda, former directorgeneral of Monbusho's Institute of Space and Astronomical Science, who has also headed RIKEN. "Scientists are often ignorant about politics, and politicians often fail to understand the importance of scientific research he is the only person with an insight and understanding of both ends of the spectrum."

Oda expressed concern that the merger of STA and Monbusho could jeopardize support for basic research, especially if the new ministry has a bureaucratic approach.

At a press conference last week, Arima said he felt "at home with both STA and Monbusho" and hoped "that the dual post would help promote science and technology in Japan".

STA and Monbusho have started to form detailed plans for the impending merger, which will involve a drastic reduction in the number of sections on both sides. According to its preliminary plan, the new ministry will have seven bureaux, including those for science and technology policy, promotion of research, research and development, and higher education.

STA's role in nuclear safety management will be reduced by the merger: the main part of its nuclear safety bureau, responsible for regulating nuclear materials, will be transferred to the Ministry of International Trade and Industry, and a section responsible for regulating reactors and radioactive material for basic research will be transferred to the new bureau of science and technology policy.

The atomic-energy bureau will be reduced to sections within the two bureaux of the promotion of research, and science and technology policy, respectively.

Large projects, such as Monju, the experimental fast-breeder reactor, will be overseen by the former, with smaller projects, such as those concerning radiation research, moving to the latter.

AsakoSaegusa 